Utilizing syllabi to support access services and beyond: A case study

\author{
Justin Parrott \& Beth Daniel Lindsay \\ New York University Abu Dhabi \\ PO Box 129188
}

Abu Dhabi, United Arab Emirates

This is an Accepted Manuscript of an article accepted for publication by Taylor \& Francis in the Journal of Access Services, published online February 15, 2017 and available at: http://www.tandfonline.com/10.1080/15367967.2017.1281138 


\begin{abstract}
New York University Abu Dhabi (NYUAD) Library receives copies of all course syllabi to provide a number of services to faculty and students related to acquisitions, access, collection development, subject liaison, and library instruction. Access services and acquisitions staff, as well as subject specialist librarians, work together using specific workflows to ensure subject-relevant materials are selected and purchased on an ongoing basis and access needs are met by course reserves or the learning management system. In addition, the library works closely with the NYUAD Bookstore, which also receives textbook orders, to ensure students have access to all required and supplementary materials on the first day of classes.
\end{abstract}

Keywords: syllabi, textbooks, course reserves, collection development, library liaison services, information literacy, academic libraries 


\section{Utilizing syllabi to support access services and beyond: A case study}

\section{Abstract \\ Introduction}

New York University Abu Dhabi (NYUAD) welcomed its first 150 students in the fall of 2010. The library collection contained only about two thousand books until shortly before faculty and students arrived. The decision was made not to purchase an "opening day" collection. Rather, the director at the time and other librarians, in consultation with Deans and other faculty leaders, selected materials for the collection based on their judgment and a review of the course syllabi. The syllabi workflow, which began as an ad hoc solution to support the first semesters of study, eventually evolved and developed into an integrated process in support of access services, collection development, and other library services.

To ensure that students would have access to whatever they needed for class, the library received copies of syllabi from the Dean's offices and ordered all recommended materials, but not required textbooks. For the first few years, nearly all students were on full financial aid and received copies of the required textbooks as part of their aid package. Thus, the library director at the time decided not to purchase required textbooks. Because the collection was so small, very little assigned by faculty was in the collection before the syllabi collection process began. The syllabi were used to guide the purchase of materials relevant not only to specific courses, but to the broader themes and topics of the University's academic programs.

There was some light resistance to the workflow in its initial phase that needed to be overcome. Some faculty members did not wish to share syllabi because it was an additional task among many other duties and they did not see the benefit. Others were protective of their work product and and concerned about copyright. The concern about copyright is not unique to NYUAD. For example, the Court of Appeals of Missouri ruled, not without controversy, 
that the University of Missouri was not required to disclose its syllabi to external parties on the grounds that they were protected by copyright law (National Council of Teachers Quality v. Curators of the University of Missouri, 2014). However, due to the small number of faculty, the amicable relationships between library staff and faculty members, the clear benefit to the students that librarians communicated, and the mutual goal of improving access to relevant materials, most of the faculty agreed to share their syllabi.

Over time, the process changed such that faculty submit their syllabi to their Dean and to the library (as opposed to the Dean's office providing it to the library). This change was in the service of transparency: faculty would know the library had a copy of their syllabus since they sent it to the library themselves. Faculty also submit an order to the bookstore for all the the materials required in their courses. The Library and the bookstore work together to ensure that students have access to materials. The bookstore began to purchase a copy every required textbook for the library to serve as a back-up if for any reason a student was unable to receive a copy on the first day of classes. This arrangement became absorbed into the syllabi workflow as the Library and the bookstore exchange information about required materials.

As a new university that draws students, faculty, and staff from around the world, NYUAD Library examines syllabi from international scholars in support of a diverse student population and globally-minded curriculum. In the words of Director Virginia Danielson, "Syllabi show a Librarian how a scholar thinks about a subject and the direction his or her teaching is likely to take,” (personal communication, November 23, 2016). The Library collects syllabi and examines them to support course reserves, film screenings, uploads to the learning management system, collection development, and instruction. Additionally, cooperation among library staff on syllabi workflow creates a synergy that broadens the staff's understanding of each other's roles and provides transferable skills should they wish to move to another role within libraries. 
The print collection at NYUAD Library supports curricular needs and it currently contains approximately 63,000 items of a total capacity of 100,000. License agreements allow full access to NYU’s global network of e-resources from on and off-campus, and users may request print materials from the main Bobst Library in NYU New York’s 6.5 million volume collection. Electronic resources and intra- and interlibrary loan can meet the research needs of faculty and advanced scholars, but the print collection in Abu Dhabi supports undergraduate students. Thus, it is imperative that librarians have a clear understanding of the undergraduate curriculum and the coursework that students complete, especially the finalyear capstone projects. Reference and instructional services in the Library need this information about the curriculum to provide relevant workshops, classroom instruction, and one-on-one reference interviews. Careful review of the majority of course syllabi is an important part of meeting this goal.

NYUAD is a liberal arts college with engineering, fully integrated with the rest of NYU’s global network including two other degree-granting campuses and eleven academic centers. NYUAD offers 22 majors in traditional liberal arts fields such as biology, economics, music and philosophy, 21 disciplinary minors and seven multi-disciplinary concentrations. Faculty and students move throughout the University’s campuses to teach, learn and conduct research; library materials move as well. ${ }^{1}$ Enrollment is currently just over 1,000 students; instructional faculty number approximately 205. Since its founding NYUAD has expanded its research footprint and includes graduate and executive education programs.

The library receives most syllabi for courses taught, but not all. Subject liaisons actively request syllabi from faculty, particularly in the humanities, if the library has not received them, as these syllabi are the most likely to contain references to material the Library may need to purchase. The syllabi workflow works in tandem with close liaison

\footnotetext{
${ }^{1}$ For more about movement of library materials, see Lindsay, Rose, Thompson and Turgel (2016).
} 
responsibilities among the University's many departments to support access to supplemental instructional and research materials. Through the combined efforts of syllabi analysis and outreach, the Library is able to enrich its services and provide a better experience to the University’s diverse community.

\section{Literature Review}

Syllabi studies appear in the literature in a variety of contexts. In one of the first to mention them in support of academic library programs, Rambler (1982) concluded that academic libraries, as well as school libraries, can use syllabi in support of library programs and specifically for decision-making "in such areas as budget allocation, collection development, and personnel assignments,” (p. 159). Library professionals have been aware for some time that the collection and study of syllabi have the potential to enrich library services and activities.

Collection development is a significant area in which syllabi inform librarians of the different needs and interests of users. Syllabi analysis can aid collection development through the ordering of specific titles, awareness among selectors of high-interest topics, whether faculty teach the topics explicitly or implicitly via optional student assignments (Williams, Cody \& Parnell, 2004). Austenfeld (2009) highlighted the importance of smaller libraries directing their collection development in relation to changing academic programs and user needs and interests. Syllabi can help anticipate the direction in which academic programs develop and librarians adjust acquisitions policy accordingly, as well as assess the needs of faculty and students (Shirkley, 2011). Librarians use syllabi to gauge the relevance and quality of resources related to specific disciplines. Johnson, Stierman, Stierman, and Clark (2013) collected syllabi from accredited doctoral programs in business to identify core journal and monograph literature related to their fields. Doing so allows collection 
development librarians to focus on the most important resources, especially given budget constraints. It also has implications for weeding the collection of less valuable material.

Librarians use syllabi studies and analyses to support information literacy and library instruction programs in a variety of disciplinary contexts. By collecting and analyzing syllabi, librarians are able to provide suggestions for improvement of outreach programs and to take advantage of more learning opportunities among their different user populations in sciences, business, and humanities (Dinkelman, 2010; Smith, Doversberger, Jones, Ladwig, Parker, \& Pietraszewski, 2012; Alcock, 2016). Many authors have suggested that the collection of data from syllabi and the resulting adjustment of library programs can produce more positive learning outcomes. VanScoy and Oakleaf (2008) recommend the use of syllabi studies to support data-driven and evidence-based decision-making in library instruction. They argue that by examining syllabi, it is possible to gain a clearer understanding of the specific information literacy skills users require and adapt a tiered instructional approach, in which skills from basic to advanced at taught at appropriate levels, based on these findings (p. 573). Boss and Drabinski (2014) attempted to establish a replicable method of analyzing course syllabi to support library instruction and information literacy programs within a specific discipline, in their case, the business program. They developed a set of content analysis questions, based upon the rubric of the Association of American Colleges \& Universities, that can be applied to the analysis of syllabi to collect actionable data for improving learning outcomes. In a similar vein, McGowan, Gonzalez and Stanny (2016) used syllabi studies to evaluate learning outcomes in relation to the ACRL Information Literacy Standards. Maybee, Carlson, Slebodnik and Chapman (2015) suggest that a grounded theory approach, a methodology used in the social sciences in which an inductive analysis of original data produces theoretical concepts, has the potential to identify several themes within curricula 
related to information literacy, resulting in an adjustment in library services to meet the needs of students and faculty.

Aside from specific programs within the library, librarians can use syllabi to gauge perceptions of the library by faculty and students. Dewald (2013) used a syllabi study to determine library usage by a specific sub-population of business students. She found that the level of research required by faculty was more than librarians had expected, leading to the development of new strategies for assisting students and collaborating with faculty.

To date, most of the literature focuses on targeted data-driven studies or the use of syllabi within a specific disciplinary context. The study of syllabi as part of a regular workflow in support of access services, alongside multiple other library activities, has not been discussed in detail. This article will add to the literature in this respect.

\section{The process: course reserves, acquisitions, and more}

The success of the syllabi workflow is dependent upon close collaboration and communication between the library, the registrar, university bookstore, and faculty, as well staff within the library in acquisitions, access, and reference services.

To begin, the acquisitions team receives the official course list from the university registrar. The document is shared by all staff members involved in the process via Google Sheets (see figure 1). ${ }^{2}$ The first four columns include basic course information; the next five relate to the workflow. Once the document is ready, it is shared with all staff members for their reference and the syllabi received can begin to be fully processed.

The University must maintain records of syllabi for all courses taught per UAE accreditation requirements. Faculty teaching new or revised courses submit their syllabus for approval. The library receives the syllabus once it is approved. Faculty may also submit their

\footnotetext{
${ }^{2} \mathrm{NYU}$ is a subscriber to Google Apps for Education, which means that all students, faculty and staff have access to the suite of Google Apps, including Docs, Sheets, Drive, and Groups. The Library uses Google Sheets as the central repository to record receipt and review of syllabi, Google Groups to coordinate receipt of syllabi, and Google Drive to store copies of syllabi.
} 
syllabus directly to the library. They often do this in advance if they need a large amount of course reserves, need a significant amount of supplementary materials to support the course, or require other special access considerations. For repeat courses, the library may download the syllabus from a central repository and review it again.

Once the library receives the syllabus, the access services team conduct the first round of searching. Based on conversations with faculty, our policy is to purchase print versions of recommended texts whenever possible. Access services staff search OPAC and Aleph by title, author, and a combination of keywords before determining that an item is not in our holdings and must be purchased. It is also assumed that the faculty requires the specific edition of a work listed on their syllabus, as variant editions of a work may contain important additional material (new foreword, introductory essay, etc.) as well as different pagination than what is listed for assigned course readings. Searching both sources also reduces (with the goal of eliminating) duplicate titles.

Access services staff note course reserve requests during this first step and process the requests before the semester begins. All materials are placed on reserve for the standard loan period of five hours. Staff also note any film screenings and contact the faculty member to confirm whether they would like to schedule loans for the screenings. The DVD collection is in open stacks and can circulate to all borrowers, so scheduling loans is the only way to ensure availability for film screenings. Staff will make sure that any technology needs related to audio-visual materials are directed to the academic technology office, which is part of the library.

Access services staff further note references to materials that may need to be uploaded to our online learning management system (NYUClasses). Journal articles, scanned book chapters, and audio-visual materials that are appropriate for the learning management system - within copyright fair use guidelines - can be added to the system as requested by faculty. 
Access services staff provide assistance with uploading materials. The library also provides training to faculty who wish to upload materials themselves. In case faculty are unsure of the amount of material they are allowed to upload within copyright restrictions, staff will determine the best solution to meet their needs, either by uploading the material or placing materials on course reserve.

After the access team conducts the preliminary check, the syllabi are transferred to the acquisitions team to places orders for items not available in the library collection. All recommended and supplementary books, films for in-class screenings, and other materials are purchased and processed through normal channels. The ordering process needs to be done well in advance of the first day of classes, as it can take up to a month for items to arrive shelf-ready in Abu Dhabi. ${ }^{3}$ These order records are noted as course materials in Aleph so that processing staff will give them priority over librarian-selected general collection development items. When the items arrive shelf-ready in Abu Dhabi, they will be placed on course reserves as noted.

Required textbooks are acquired directly from the bookstore. Although all students should have access to these textbooks via the bookstore, there are gaps that occur sometimes during course registration or book ordering that result in one or more students not having access to their required materials on the first day of class. The textbook provided to the library serves as a back-up. Book chapters and readings can be scanned - within copyright and uploaded to the learning management system or placed on course reserve. Moreover, the library copy is more easily acquired directly from the bookstore when it is the international version of a North American textbook.

\footnotetext{
${ }^{3}$ For more on NYUAD's technical services workflows, see the chapter "Global Strategy for Technical Services" (p.183-192) in Pun, Collard, \& Parrott (2016).
} 
Library staff communicate regularly with the bookstore in order to share information that serves the functions of both departments. In order to save on costs, library staff inform the bookstore of the required textbooks the library needs in order to avoid duplication from repeat courses. In turn, if the bookstore is unable to supply a particular title to all students, they will inform the library so that the item can be scanned or placed on course reserve as appropriate, thereby ensuring students access to the materials. Sometimes new faculty, unaware of the difference between the library and bookstore, tell the bookstore about their course reserve requests, special needs, or last-minute changes to textbook orders. The bookstore staff will pass this information to the library team. On the other hand, faculty might deliver their textbook order to the library, in which case this information is directed to the bookstore.

After the ordering process is complete, hard copies of the syllabi are retained in folders according to faculty last name. Digital copies are saved in a shared Google Drive folder with a standardized filme name according to course number, title, and instructor. This is the syllabi archive. These files serve as resources for library staff in the event that syllabi need to be consulted again later, as well as an informal repository of information on how instructional programs have developed over time.

The division of labor has the added value of creating synergy between the acquisitions and access services teams. Staff members gain transferable skills to prepare them for future career directions. Further, in the beginning, no staff members were familiar with the OPAC or Aleph searching, and this task as part of the syllabi workflow provides continual practice and improvement of their searching skills. This also means that access services staff are better able to help users with simple questions about searching the catalog, particularly in the evenings and weekends when reference librarians are not available. 
While the syllabi workflow has provided great benefits and has become an important support of NYUAD's access services, it does have limitations that must be addressed in other ways. As noted, the library is not able to collect all of the syllabi in every semester. Some syllabi will inevitably be left out, for whatever reason, or received too late for access services to act upon. Syllabi are also not uniformly formatted and presented; the required or recommended materials are not neatly listed near the top, or bibliographic information about the items is incomplete. For this reason, the course list and syllabi archive are shared with liaison librarians who effectively communicate with their designated faculty to acquire information the access services team needs, as well as to support other library activities.

\section{Liaisons: collection development, outreach, and instruction}

At NYUAD, liaison librarians have responsibility for collection development, outreach, and instruction in their assigned subjects and majors. All liaisons contact their assigned teaching faculty each semester, introducing or reminding them about the variety of library services available to them. These messages also include requests and reminders for faculty to provide information about their specific requests, such as course reserves, in case the library was unable to acquire their syllabus for whatever reason. Liaison who conduct outreach to faculty are essential in this role to fill the gaps in access services not fully covered by the collection of syllabi.

The course list and syllabi archive folders in Google Drive are an important part of liaison work between subject librarians, faculty, and students. The shared course list spreadsheet serves as a reference for librarians of their assigned courses and faculty contacts. The list can be sorted so that all the librarian's instructors appear together, allowing librarians to easily gather the names of those they need to contact. This is especially helpful as the University grows larger, adding more and new faculty every year. In addition, the course list is the space where liaison duties related to the Core, or general education requirements, are 
assigned and recorded. Core courses often overlap subject matters by virtue of their interdisciplinary nature. Subject librarians examine the course descriptions or recognize familiar faculty names to decide among themselves who is best suited to provide support to that particular course.

Throughout the academic year, subject librarians will refer to the syllabi to aid their collection development duties. The University's academic programs often develop in unexpected ways and directions, including new geographic, scientific, or humanities components. Librarians can learn more about the direction of academic programs and about their specialized fields overall by examining the course descriptions, topics, and materials listed on the syllabi. They can also identify the seminal or leading works in the field, according to the faculty, and use citation mining within the bibliographies of these materials to select materials for purchase.

Syllabi collection has been an integral part of preparing the library to serve new academic programs. During Fall 2016, NYUAD launched a new legal studies program specializing in comparative law across North America, Europe, and the Gulf States. The curriculum has so far focused on UK and UAE law in addition to US and other legal systems. The library had not collected in these areas before the launch of the new program. In consultation with the faculty, the subject specialist used the program's syllabi to build a basic collection of reference and introductory works that would support student research in the first semester. The liaison librarian also became familiar with online resources for UK and UAE law to be able to provide classroom instruction sessions on their use and to assist students in one-on-one research consultations.

When faculty request that librarians visit classes for instruction sessions, librarians are usually able to review the current year's syllabi to gain valuable information such as assignment descriptions, due dates, course meeting times, and locations. This information is 
tremendously helpful as it lessens the burden on faculty members to explain themselves while facilitating the librarians’ planning for suitable instruction sessions. Reading the entire syllabus, not only the assignment section, gives the librarian insight into what the instructor wants the students to learn and what resources they ought to be familiar with. Liaison librarians have found that examining syllabi is a good method of constructing examples in citation workshops and classroom instruction. By referencing materials that have been or will be taught in a particular course, instruction librarians can make their content more relevant to the needs of the students.

As liaison duties transfer to new librarians, the syllabi archive is a useful tool for familiarizing incoming hires with the academic programs they will support. Rather than starting from scratch, new liaisons can use the wealth of information in the syllabi archive to quickly form a picture of what is being taught in the classroom. The storage of the syllabi archive in this way ensures continuity as duties and personnel change over time.

\section{Conclusion}

The success of the NYUAD Library's syllabi workflow is evidenced in positive feedback that users - faculty and students - have expressed formally in surveys and informally outreach events. The recent LibQual+ (2016) survey results indicate that the access and collection development strategy is working: users rated the library's print and electronic resources as more than adequate (p. 33), and students rated the availability of print materials needed for their work more highly than did faculty (p. 45, 71). This discrepancy is expected since the library aims to support the undergraduate curriculum. Users expressed their satisfaction as the collection has grown over the years from a few thousands books to over 60,000 volumes at the time of this writing, a majority of which (approximately 60\%) were manually selected firm orders (as opposed to automatic purchases via the Library’s approval plan). Thus, it can be confidently said that the syllabi workflow was an important component 
of building a relevant and high-quality collection for the University's diverse student population.

The syllabi workflow was particularly useful to NYUAD Library during the University's start-up phase when the faculty and student population was small. This allowed a basic workflow to be constructed that could then evolve into a major component of access and collection development strategy. Once the process had been established, it was possible to maintain and expand the service to extract the most benefit possible to the library and its community. The workflow described here may be most suitable for smaller, emerging libraries to model, rather than larger established institutions. Even so, this experience demonstrates that access to syllabi can enrich multiple library services in creative ways.

Because the library began collecting and reviewing syllabi as an ad hoc solution to meet its start-up needs, the assessment of the workflow on a quantitative level has not been undertaken. Formal and targeted assessment data that can prove the effectiveness of the strategy has not been collected. However, LibQUAL+ results indicating user satisfaction with print collections, particularly from undergraduates, offer qualitative indications of our strategy's success. Further, liaison librarians who have relationships with faculty and students feel confident, on the basis of informal feedback, that the our collection and services are meeting their needs.

\section{References}

Alcock, E., \& Rose, K. (2016). Find the gap: evaluating library instruction reach using syllabi. Journal of Information Literacy, 10(1), 86. https://doi.org/10.11645/10.1.2038 Association of Research Libraries (2016). LibQUAL + 2016 Survey: library branch analysis, New York University Libraries - NYU Abu Dhabi Library. Washington, DC. 
Austenfeld, A. M. (2009). Building the College Library Collection to Support Curriculum Growth. Collection Management, 34(3), 209-227. https://doi.org/10.1080/01462670902975027

Boss, K., \& Drabinski, E. (2014). Evidence-based instruction integration: a syllabus analysis project. Reference Services Review, 42(2), 263-276. https://doi.org/10.1108/RSR-072013-0038

Dewald, N. H. (2003). Anticipating library use by business students: the uses of a syllabus study. Research Strategies, 19(1), 33-45. https://doi.org/10.1016/j.resstr.2003.09.003

Dinkelman, A. L. (2010). Using course syllabi to assess research expectations of biology majors: Implications for further development of information literacy skills in the curriculum. Issues in Science and Technology Librarianship, (60), 5.

Johnson, D. T., Stierman, J. K., Stierman, J. P., \& Clark, B. F. (2013). Using Syllabi to Determine the Core Journal and Monographic Literature in Doctoral Finance Programs. Journal of Business \& Finance Librarianship, 18(3), 191-207. https://doi.org/10.1080/08963568.2013.794666

Lindsay, B.D., Rose, K., Thompson, S., \& Turgel, S.. (2016). Creating Global Delivery Strategy: Services, Systems and Practices. In R. Pun, S. Collard, \& J. Parrott (Eds.), Bridging worlds: emerging models and practices of U.S. academic libraries around the globe.

Maybee, C., Carlson, J., Slebodnik, M., \& Chapman, B. (2015). “It's in the Syllabus”: Identifying Information Literacy and Data Information Literacy Opportunities Using a Grounded Theory Approach. The Journal of Academic Librarianship, 41, 4, 369-376. McGowan, B., Gonzalez, M., \& Stanny, C. J. (2016). What Do Undergraduate Course Syllabi Say about Information Literacy? Portal: Libraries and the Academy, 16(3), 599-617. 
National Council of Teachers Quality v. Curators of the University of Missouri 446 S.W.3d 723

(Court of Appeals of Missouri, Western District, Division Four, 2014)

NYU Abu Dhabi. (2016). NYU Abu Dhabi Bulletin 2016-17.

Pun, R., Collard, S., \& Parrott, J. (Eds.) (2016). Bridging worlds: Emerging models and practices of U.S. academic libraries around the globe. Chicago, Illinois: Association of College and Research Libraries.

Rambler, L.K. (1982). Syllabus Study: Key to a Responsive Academic Library. Journal of Academic Librarianship, 8(3), 155.

Shirkey, C. (2011). Taking the Guesswork Out of Collection Development: Using Syllabi for a User-Centered Collection Development Method. Collection Management, 36(3), 154-164. https://doi.org/10.1080/01462679.2011.580046

Smith, C., Doversberger, L., Jones, S., Ladwig, P., Parker, J., \& Pietraszewski, B. (2012). Using course syllabi to uncover opportunities for curriculum-integrated instruction. Reference \& User Services Quarterly, 51(3), 263-271.

VanScoy, A., \& Oakleaf, M. J. (2008). Evidence vs. Anecdote: Using Syllabi to Plan Curriculum-Integrated Information Literacy Instruction. College \& Research Libraries, 69(6), 566-575. https://doi.org/10.5860/crl.69.6.566

Williams, L. M., Cody, S. A., \& Parnell, J. (2004). Prospecting for new collaborations: Mining syllabi for library service opportunities. The Journal of Academic Librarianship, 30(4), 270-275. 